\title{
Trace Elements Content in the Pink Salmon (Oncorhynchus gorbuscha Walbaum, 1792) from Sakhalin-Kuril Region
}

\author{
Nadezhda K. Khristoforova ${ }^{1,2}$, Anna V. Litvinenko ${ }^{3}$, Vasiliy Yu. Tsygankov ${ }^{4}$, Maxim V. Kovalchuk ${ }^{5,6}$, and \\ Natalia I. Erofeeva ${ }^{4}$ \\ ${ }^{1}$ School of Natural Sciences, Far Eastern Federal University, Vladivostok 690091, Russia \\ ${ }^{2}$ Pacific Institute of Geography, Far Eastern Branch, Russian Academy of Sciences, Vladivostok 690041, Russia \\ ${ }^{3}$ Sakhalin State University, Yuzhno-Sakhalinsk 693008, Russia \\ ${ }^{4}$ School of Biomedicine, Far Eastern Federal University, Vladivostok 690091, Russia \\ ${ }^{5}$ Institute of Marine Geology and Geophysics, Far Eastern Branch, Russian Academy of Sciences, Yuzhno- \\ Sakhalinsk 693022, Russia \\ ${ }^{6}$ Pacific Research Fisheries Center, Vladivostok 690091, Russia
}

Keywords: Pacific salmon, pink salmon, Sakhalin-Kuril region, trace elements, impact zone

The Sakhalin-Kuril region (SKR) is one of the main areas of catch of Pacific salmon in the Far East of Russia. The leading fishing facilities are pink salmon (Oncorhynchus gorbuscha) and chum salmon (O. keta). In 2016, the catch of these species in the SKR amounted to 105.4 thousand metric tons ( 74 thousand metric tons of pink salmon and 31.4 thousand metric tons of chum salmon), which was almost one quarter of the production of these salmon in the Far East of Russia. The total capacity of fish-breeding enterprises at the end of 2015 amounted to 956.5 million salmon fry (Report 2016). Most of the plants in the SKR are located in the southern part of Sakhalin and in the Central part of the Iturup Island, on the coast of the Sea of Okhotsk.

In autumn, the Okhotsk pink salmon offspring begin to migrate into the ocean to the Polar front zone. Salmon feed in the spring in the area near Kuril Islands, then head to spawn in native rivers (Shuntov 2001; Temnykh 2004).

The Kuril-Kamchatka region is characterized by the impacts of geochemical conditions that are created by upwelling, underwater and surface volcanism, which carry biogenic and other elements from the depths of the KurilKamchatka trench. The Kuril Island region supplies the surrounding Pacific Ocean waters with a high content of chemicals due to volcanic and seismic activities. Pacific salmon which swim out for the winter and migrate to spawn, encounter these chemicals. This inevitably leaves its "trace" in the microelement composition of fish organs and tissues, which regulates the levels of elements, particularly toxic ones, that are caught in the fishery hydrobionts (Kovekovdova 2011; Kovekovdova et al. 2013; Khristoforova et al. 2014; Khristoforova et al. 2015a; Khristoforova et al. 2015b; Khristoforova et al. 2016; Khristoforova et al. 2018). However, there is limited information about how micronutrient content in active swimmers varies during their extensive migrations, such as Pacific salmon during feeding, wintering and spawning when they pass through geochemically impacted zones.

The purpose of this work is to determine the concentrations of trace elements in the pink salmon tissuesreturning to the river Reidovaya (Iturup Island) and the river Firsovka (the southern part of the Eastern Sakhalin).

\section{Material and methods}

Essential (Zinc and Copper) and non-essential (Nickel, Cadmium, Lead, Arsenic, Mercury) elements were quantified. All of them can be tracers of natural biogeochemical provinces. This was repeatedly noted earlier in the study of the content of heavy metals $\mathrm{Fe}, \mathrm{Mn}, \mathrm{Zn}, \mathrm{Cu}, \mathrm{Cd}, \mathrm{Pb}, \mathrm{Ni}, \mathrm{Cr}$ in marine benthic organisms from the shallow waters of the Kuril Islands and organisms-fouling navigation buoys (Kavun and Khristoforova 1991; Malinovskaya and Khristoforova 1997; Kavun et al. 2002).

Our study focused on mature pink salmon individuals (O. gorbuscha Walbaum, 1792) that spawned in the Reidovaya river and Firsovka in early October 2016 from the fish farms "Reidovy" and "Firsovka" (Fig. 1). The producers were kept in cages at the hatcheries until they sexually matured, at which point three females and three males were selected. All elements except $\mathrm{Hg}$ were determined from an acid mineralization according to GOST 26929-94 on an atomic absorption spectrophotometer Shimadzu AA 6800. Data on the mass concentration of $\mathrm{Hg}$ was obtained by the method of stripping voltammetry at the analyzer "Tom'analit" (TA-4) (Khristoforova et al. 2015b). The results are presented in $\mu \mathrm{g} \cdot \mathrm{g}^{-1}$ of crude mass (Table. 1). For comparison, our data on the concentrations of elements in pink salmon caught in the ocean waters near the Kuril Islands in July 2013, as well as data on the 
ranges of their contents in pink salmon from the Sea of Japan are presented (Kovekovdova 2011). The mean value, standard deviation, and validity of the differences compared (using the Mann-Whitney U-test) were calculated in SPSS Statistics 21 for Mac OS X.

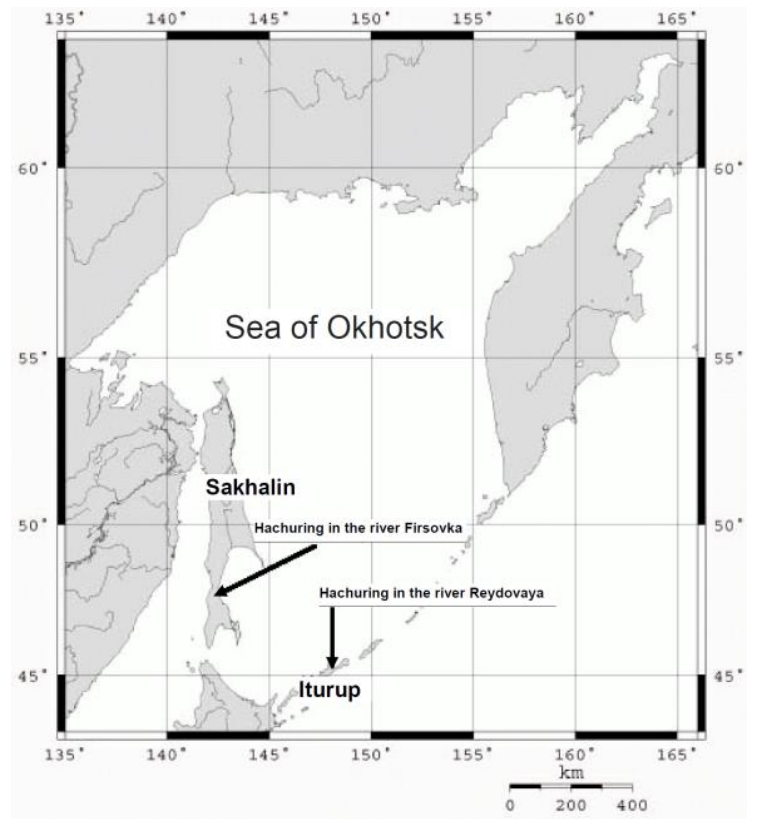

Fig. 1. Location map of the "Firsovka" and "Raidovy" hatcheries in the Sakhalin-Kuril region.

Table 1. Trace elements in organs and tissues of pink salmon of the Sakhalin-Kuril region and comparison areas, $\mu \mathrm{g} \cdot \mathrm{g}^{-1}$ of crude mass $(\mathrm{m} \pm \sigma)$.

\begin{tabular}{|c|c|c|c|c|c|c|c|}
\hline & $\mathbf{Z n}$ & $\mathrm{Cu}$ & $\mathbf{N i}$ & Cd & $\mathbf{P b}$ & As & Hg \\
\hline $\begin{array}{l}\text { Organs } \\
\text { and } \\
\text { tissues }\end{array}$ & Sakhal & island. Hatc & ery "Firso & a", 06.10.20 & 6 , the weight & ange of fish & $80-2100 \mathrm{~g}$ \\
\hline Muscles & $1.74 \pm 0.061$ & $0.20 \pm 0.040$ & $0.09 \pm 0.008$ & $0.08 \pm 0.009$ & $0.59 \pm 0.050$ & $0.90 \pm 0.074$ & $0.03 \pm 0.009$ \\
\hline Liver & $2.86 \pm 0.065$ & $0.28 \pm 0.012$ & $0.13 \pm 0.006$ & $0.19 \pm 0.018$ & $0.92 \pm 0.035$ & $1.12 \pm 0.096$ & $0.09 \pm 0.009$ \\
\hline $\begin{array}{l}\text { Gonads of } \\
\text { males }\end{array}$ & $2.76 \pm 0.021$ & $0.26 \pm 0.014$ & $0.11 \pm 0.006$ & $0.12 \pm 0.012$ & $0.87 \pm 0.014$ & $1.09 \pm 0.035$ & $0.07 \pm 0.003$ \\
\hline eggs & $2.51 \pm 0.058$ & $0.25 \pm 0.016$ & $0.12 \pm 0.007$ & $0.11 \pm 0.019$ & $0.82 \pm 0.043$ & $0.98 \pm 0.049$ & $0.07 \pm 0.004$ \\
\hline \multicolumn{8}{|c|}{ Iturup Island. Hatchery "Reidovy". 09.10. 2016, the weight range of fish 1278-2362 $\mathrm{g}$} \\
\hline Muscles & $1.96 \pm 0.075$ & $0.24 \pm 0.076$ & $0.12 \pm 0.007$ & $0.14 \pm 0.012$ & $0.67 \pm 0.050$ & $0.94 \pm 0.064$ & $0.04 \pm 0.005$ \\
\hline Liver & $3.14 \pm 0.069$ & $0.32 \pm 0.034$ & $0.18 \pm 0.009$ & $0.21 \pm 0.018$ & $0.96 \pm 0.035$ & $1.25 \pm 0.098$ & $0.12 \pm 0.009$ \\
\hline $\begin{array}{l}\text { Gonads of } \\
\text { males }\end{array}$ & $3.09 \pm 0.045$ & $0.33 \pm 0.071$ & $0.18 \pm 0.009$ & $0.19 \pm 0.034$ & $0.89 \pm 0.014$ & $1.14 \pm 0.085$ & $0.11 \pm 0.008$ \\
\hline eggs & $3.01 \pm 0.078$ & $0.29 \pm 0.036$ & $0.15 \pm 0.008$ & $0.18 \pm 0.035$ & $0.84 \pm 0.045$ & $1.13 \pm 0.086$ & $0.09 \pm 0.006$ \\
\hline \multicolumn{8}{|c|}{$\begin{array}{l}\text { Ocean waters near the Kuril Islands, July 2013, fish mass range 1168-1458 g } \\
\text { (by: Khristofor ova et al., 2015) }\end{array}$} \\
\hline Muscles & $1.29 \pm 0.079$ & $0.108 \pm 0.012$ & Not detect. & $0.037 \pm 0.005$ & $0.503 \pm 0.059$ & $0.930 \pm 0.093$ & $0.030 \pm 0.009$ \\
\hline Liver & $2.97 \pm 0.089$ & $0.165 \pm 0.008$ & & $0.152 \pm 0.015$ & $0.902 \pm 0.108$ & $1.118 \pm 0.089$ & $0.120 \pm 0.021$ \\
\hline $\begin{array}{l}\text { Gonads of } \\
\text { males }\end{array}$ & $2.43 \pm 0.029$ & $0.090 \pm 0.010$ & & $0.017 \pm 0.006$ & $0.297 \pm 0.029$ & $0.310 \pm 0.017$ & $0.053 \pm 0.006$ \\
\hline eggs & $2.35 \pm 0.076$ & $0.087 \pm 0.006$ & & $0.023 \pm 0.006$ & $0.327 \pm 0.025$ & $0.337 \pm 0.060$ & $0.070 \pm 0.010$ \\
\hline \multicolumn{8}{|c|}{$\begin{array}{l}\text { Sea of Japan, range of trace elements found in 1992, 2001, } 2008 \\
\text { (by: Kovekovdova, 2011) }\end{array}$} \\
\hline Muscles & $0.57-3.25$ & $0.032-0.087$ & & $0.005-0.012$ & $0.012-0.013$ & $0.300-1.370$ & $0.007-0.015$ \\
\hline Liver & $3.00-4.35$ & $0.119-0.165$ & & $0.080-0.145$ & $0.020-0.025$ & $0.450-0.800$ & $0.010-0.025$ \\
\hline eggs & $2.90-3.90$ & $0.037-0.090$ & & $0.001-0.003$ & $0.007-0.020$ & $0.100-0.320$ & $0.003-0.005$ \\
\hline
\end{tabular}

Note. Maximum Permissible Concentration (MPC) of toxic elements ( $\mathrm{mcg} \cdot \mathrm{g}^{-1}$ of raw mass) in seafood in Russia: $\mathrm{Pb}-1.0, \mathrm{As}-5.0, \mathrm{Cd}-0.2, \mathrm{Hg}-0.2(\mathrm{SanPiN} . ., 2002)$; in Canada: $\mathrm{Hg}-0.5$; in the USA: $\mathrm{Cd}-3, \mathrm{~Pb}-1.5, \mathrm{As}-$ 86.

\section{Results}

Mercury $(\mathrm{Hg})$ had the lowest concentrations of all the trace elements. Salmon from Firsovka had $\mathrm{Hg}$ concentrations of $0.03 \pm 0.009 \mu \mathrm{g} \cdot \mathrm{g}^{-1}$ in their muscles, and the gonads (male and female) had $\mathrm{Hg}$ concentrations of 
$0.07 \pm 0.003$ and $0.07 \pm 0.004 \mu \mathrm{g} \cdot \mathrm{g}^{-1}$ in males and females, respectively. In Reidovaya salmon, $\mathrm{Hg}$ concentrations in muscles were $0.04 \pm 0.005 \mu \mathrm{g} \cdot \mathrm{g}^{-1}$, while the gonads of males and females had $\mathrm{Hg}$ concentrations of $0.11 \pm 0.008$ and $0.09 \pm 0.006 \mu \mathrm{g} \cdot \mathrm{g}^{-1}$, respectively. $\mathrm{Ni}$ and $\mathrm{Cd}$ are characterized by minor amounts in the gonads of pink salmon but are found in larger amounts than $\mathrm{Hg}$. Ni was 1.2-1.5 times higher than $\mathrm{Cd}$ in the muscles, however in the muscles and gonads of fish from the hatchery "Firsovka," Cd distribution was almost identical to Ni. In pink salmon from the hatchery "Reidovy," there were greater concentrations of $\mathrm{Cd}$ than $\mathrm{Ni}$, typically $0.14 \pm 0.012$ in the muscle and $0.19 \pm 0.034$ and $0.18 \pm 0.035 \mu \mathrm{g} \cdot \mathrm{g}^{-1}$ in the male and female gonads, respectively. $\mathrm{Cu}$ was found to be twice the concentration of $\mathrm{Ni}$ in the muscles and gonads of salmon, with subsequent increasing concentrations of $\mathrm{Pb}$, As and $\mathrm{Zn}$. The levels of $\mathrm{Pb}$ in the fish organs and tissues were as follows: muscle varied from $0.59 \pm 0.050$ to $0.67 \pm 0.050$ $\mu \mathrm{g} \cdot \mathrm{g}^{-1}$, male gonads ranged from 0.014 to $0.89 \pm 0.014 \mu \mathrm{g} \cdot \mathrm{g}^{-1}$, and the calf of females was between $0.82 \pm 0.043$ and $0.84 \pm 0.045 \mu \mathrm{g} \cdot \mathrm{g}^{-1}$. It is important to note that the concentrations of toxic elements in the studied pink salmon individuals did not exceed the maximum Russian permissible concentration in foods (PC) and were below the standards adopted in Canada and the United States. Despite the mercury concentrations in Iturup salmon being five times lower in the muscle and two times below PC in the calf, concentrations of $\mathrm{Pb}$ in male and female pink salmon gonads from the island are approaching Russian sanitary standards. Levels of $\mathrm{Pb}$ in pink salmon muscle were 1.5 and 1.7 times lower than PC in fish from Iturup and Sakhalin, respectively. Cd concentration is also close to PC and almost reaches its value in the gonads of fish from "Reidovy." In the gonads of salmon from "Firsovka" and in the fish muscle of fish from both plants, the concentrations of this toxic element were approximately half the acceptable PC. Only concentrations of As were significantly below PC where even the gonads did not exceed $1 / 4$ of the permissible concentration. Thus, the concentration of $\mathrm{Pb}$ and $\mathrm{Cd}$ in the pink salmon of the Sakhalin-Kuril region are close to the sanitary standard. The concentrations of these elements in the fish fillet are well below the amount allowed by sanitary standards and do not cause any concerns for consumers (Sanitary rules. 2002).

\section{Discussion}

According to the level of pink salmon stock in the Sakhalin-Kuril region, the three most important areas are the Iturup Island, the Southeastern coast of Sakhalin and the Aniva Bay. In catches on the East coast of Sakhalin and the Southern Kuril Islands, the late (autumn) form of pink salmon dominates (Kaev 2007).

In a previous study, the trace element composition of pink salmon caught in July 2013 in the Kuril Islands waters of the Pacific Ocean during its anadromous migration to the rivers of the Sea of Okhotsk were described (Khristoforova et al. 2015b). However, the present work studied pink salmon in October 2016 as they moved from the ocean into their native river, which would be their second time crossing the very rich waters of the KurilKamchatka Region.

The difference between the trace elements found in the muscle and liver of salmon from the ocean waters near the islands did not exceed twice the amount found in fish from the Firsovka River. Sakhalin fish had much more variation in the levels detected in their tissues, which were 3-7 times higher than the fish from other areas (Table 1). Pink salmon from the Sea of Japan had the lowest concentrations of elements, which were significantly lower than in the fish of the Sakhalin-Kuril region. The greatest differences were found for $\mathrm{Pb}$, whose concentration in muscles, liver and eggs of SKR fish was approximately 50 (49-56), 40 (42-44) and 60 (63-65) times higher, respectively, than in pink salmon from the Sea of Japan.

The exception to these findings was $\mathrm{Zn}$, where greater concentrations were detected in the organs and tissues of pink salmon from the the Sea of Japan compared to fish in the SKR, which is a consequence of the anthropogenic influence on the Sea of Japan.

During winter, the fish that reproduce in the rivers of the Sakhalin-Kuril basin feed in the Sea of Japan and in the North-West Pacific Ocean. From the feeding area in the Sea of Japan, pink salmon migrate to spawn in the rivers of Northern Primorye, Western Sakhalin, the Amur basin, as well as Eastern Sakhalin, the southern Kuril Islands and the rivers flowing into the Aniva Bay. However, they mainly reproduce in the rivers of the first three regions. Fishing is based on the late oceanic group, which are selected based on the study of salmon.

Therefore, as the Asian pink salmon leave the nursery and return to spawn, not all of them will pass through the impact zone on the Kuril Island, or specifically pass by it on the seaside (the Sea of Japan) (Khristoforova et al. 2015b).

Pacific salmon (specifically Sakhalin-Kuril pinks) often feed in a high-altitude area (145 to $165^{\circ} \mathrm{E}$ and South to $40^{\circ} \mathrm{N}$ ) where there is an abundance of zooplankton (Birman 1974). These zooplankton, which have absorbed copious amounts of phytoplankton growing on biogenic and other elements supplied by volcanism and upwelling in this area, transmit the microelements in their biomass to organisms of the next trophic level, including Pacific salmon. 
The pink salmon that spawned in October migrated through the rivers of Reidovaya and Firsovka, which means that they were feeding in the North-Western Pacific Ocean and passed through the impacted geochemical zone twice. The transfer of trace elements through trophic levels explains why these salmon had significantly higher concentrations of all trace elements (except $\mathrm{Zn}$ ) compared to the Japanese pink salmon.

Immature pink salmon that were caught in the ocean waters near Kuril Islands in July 2013 had to swim from the Sea of Okhotsk to the Southeast zone of the subarctic front from the southern and central parts of the Kuril Ridge (Shuntov and Temnykh 2011). These fish were captured on the outskirts of the geochemical impact zone and can not have accumulated the same levels of microelements compared to mature fish that came to spawn in the rivers Reidovaya and Firsovka.

\section{REFERENCES}

Birman, I.B. 1974. The marine period of life and the dynamics of the herd of Pacific salmon. Ph.D. thesis, AllUnion Institute of Marine Fisheries and Oceanography (VNIRO), Moscow. 39 pp. (In Russian)

Kaev, A.M. 2007. Commercial and biological characteristics of pink salmon in Sakhalin and the South Kuril Islands in 2007. Bull. No. 2 of the implementation of the "Concept of the Far Eastern Basin Program for the Study of Pacific Salmon”. TINRO-Center: 21-26. (In Russian)

Kavun, V.Ya., and N.K. Khristoforova. 1991. The role of modern volcanism and upwelling in the formation of impact zones of heavy metals in the coastal waters of the Kuril Islands. Shallow-water gas-hydrotherms and the ecosystem of the Kraternaya Bay (Ushishir Volcano, Kuril Islands). Prince 1, part two. Vladivostok: Far Eastern Branch of the Russian Academy of Sciences. 120 pp. (In Russian)

Kavun, V.Ya., V.M. Shulkin, and N.K. Khristoforova. 2002. Metal accumulation in mussels of the Kuril Islands, north-west Pacific Ocean. Mar. Environ. Res. 53: 219-226.

Kovekovdova, L.T. 2011. Trace elements in the marine fishing facilities of the Far East of Russia. Ph.D. thesis. TINRO-Center, Vladivostok. 40 pp. (In Russian)

Kovekovdova, L.T., M.V. Simokon, and D.P. Kiku. 2013. Trace element composition of commercial fish of the Far Eastern seas. Problems of Regional Ecology. 2: 72-75. (In Russian with English abstract)

Khristoforova, N.K., V.Yu. Tsygankov, and M.D. Boyarova, O.N. Lukyanova. 2014. The Role of the Biogeochemical Conditions of the Marine Environment on the Trace Element Content in Pacific Salmon. Achievements in the Life Sciences. 8: 55-60.

Khristoforova, N.K., V. Yu. Tsygankov, M.D. Boyarova, and O.N. Lukyanova. 2015a. The content of trace elements in Pacific and Atlantic salmon. Oceanology. 55(5): 751-758. (In Russian with English abstract)

Khristoforova, N.K., V.Yu. Tsygankov, M.D. Boyarova, and O.N. Lukyanova. 2015b. The content of heavy metals in the pink salmon Oncorhynchus gorbuscha Walbaum, 1792 from the Kuril waters during anadromous migration. Biology of the sea. 41(6): 447-452. (In Russian with English abstract)

Khristoforova, N.K., V.Yu. Tsygankov, O.N. Lukyanova, and M.D. Boyarova. 2016. The Kuril Islands as a Potential Region for Aquaculture: Trace Elements in Chum Salmon. Environ. Pollut. 213: 727-731.

Khristoforova N.K., V.Yu. Tsygankov, O.N. Lukyanova, and M.D. Boyarova. 2018. High mercury bioaccumulation in Pacific salmons from the Sea of Okhotsk and the Bering Sea. Environ. Chem. Lett. 16: 575-579.

Malinovskaya, T.M, and N.K. Khristoforova. 1997. Characteristics of the coastal waters of the southern Kuriles on the content of trace elements in indicator organisms. Sea Biology. 23(4): 239-246. (In Russian with English Abstract).

Report on the environmental situation and environmental protection in the Sakhalin region in 2015 / Ministry of Natural Resources and Environmental Protection of the Sakhalin region. 2016. Yuzhno-Sakhalinsk: LLC "Eykon". 208 pp. (In Russian)

Sanitary rules and regulations 2.3.2.1078-01 Hygienic safety requirements and nutritional values of food. 2002. Moscow: State Committee for Sanitary Epidemiological Surveillance of the Russian Federation. 156 pp. (In Russian)

Shuntov, V.P. 2001. Biology of the Far Eastern seas of Russia. T.1. Vladivostok: TINRO-Center. 580 pp. (In Russian)

Shuntov, V.P., and O.S. Temnykh. 2011. Pacific salmon in marine and oceanic ecosystems: a monograph. Vladivostok: TINRO-Center. T. 1. 473 pp. (In Russian)

Temnykh, O.S. 2004. Asian pink salmon in the marine period of life: biology, spatial differentiation, place and role in pelagic communities. Ph.D. thesis. TINRO-Center, Vladivostok. 47 pp. (In Russian) 